\title{
Modelling Attitude towards Consumption of Vegan Products
}

\author{
Isabel Miguel ${ }^{1}$, Arnaldo Coelho ${ }^{2}$ and Cristela Maia Bairrada ${ }^{2, *(D)}$ \\ 1 Faculty of Economics, University of Coimbra, 3004-512 Coimbra, Portugal; uc2015173275@student.uc.pt \\ 2 CeBER, Faculty of Economics, University of Coimbra, 3004-512 Coimbra, Portugal; acoelho@fe.uc.pt \\ * Correspondence: cristela.bairrada@uc.pt
}

\begin{abstract}
This study proposes to understand the impact of personal (health awareness and social influence) and moral (environmental concerns and animal welfare) antecedents on attitudes towards veganism and their effects on engagement with vegan products, along with their impact on purchase intention and word of mouth. Idealism is presented as a moderator of these proposed relationships. The study uses a structured questionnaire to gather data from two cross-sectional samples of 224 Portuguese and 356 Brazilian vegans collected from Facebook groups of vegans. Structural equation modelling is used to test the seven proposed hypotheses and the moderation effects. This research compares the influence of personal and moral determinants on veganism using idealism as a specific context to investigate their relationships, comparing Brazilian and Portuguese respondents and the effects of national cultures. Results show that attitudes towards veganism do not depend on personal causes, but rather on moral concerns. Motivations to reduce animal consumption, protect nature, and respect animal life seem to be guided by ethical principles.
\end{abstract}

Keywords: vegan products; attitudes; involvement; vegan lifestyle; idealism

\section{Introduction}

The number of people who are vegan is increasing considerably, including in the

check for updates

Citation: Miguel, I.; Coelho, A.; Bairrada, C.M. Modelling Attitude towards Consumption of Vegan Products. Sustainability 2021, 13, 9. https: / / dx.doi.org/10.3390/su13010009

Received: 23 October 2020

Accepted: 18 December 2020

Published: 22 December 2020

Publisher's Note: MDPI stays neutral with regard to jurisdictional claims in published maps and institutional affiliations.

Copyright: () 2020 by the authors. Licensee MDPI, Basel, Switzerland. This article is an open access article distributed under the terms and conditions of the Creative Commons Attribution (CC BY) license (https: / / creativecommons.org/ licenses/by/4.0/).
Americas, Europe, and different regions of Asia [1-3]. In the past decades, researchers sought to understand how veganism is seen, approached, and understood by physicians, companies, and the nonvegan population [4]. Veganism is more than a diet; it is also a lifestyle that has been growing every year. The impact that this routine has on buyers and sellers must be valued and studied. Even though vegans are fewer in number, the influence of veganism in the food market is growing [4]. Searching on an online bookstore such as Waterstones, in September 2019, one would find 2779 book titles with the word "vegan" in them. Going back just 1 year, in August there were only 994 book titles [5]. According to the Vegan Society's website, "Veganism is a way of living which seeks to exclude, as far as is possible and practicable, all forms of exploitation of, and cruelty to, animals for food, clothing or any other purpose" [6]. Being vegan is not only having a different diet. It also implies being aware of not consuming any products made of animals, for example, leather shoes or makeup tested on animals. Veganism refers to "a particular dietary style that entails eating only plant-based foods and abstaining from all animal products" [7].

Social context enables and stimulates vegan consumption; vegan consumption practices are shaped and are part of a rising cultural movement [8]. Additionally, some authors $[3,9,10]$ state that this particular diet selection is somehow multidimensional and energetic. Therefore, sociocultural circumstances, individual preferences, and conditions influence people's diet and choices. Therefore, it seems that people generally depend on an identity that tells them how to eat, and attitudes towards veganism can be analyzed by understanding consumer behavior through three determining factors that can affect daily actions: attitudes, subjective norms, and perceived control $[3,9]$. The theory of planned behavior (TPB) [11] allows the verification of the influence that personal and social determinants have on behavior. 
The vegan philosophy has some difficulty when it comes to effectively disseminating concepts and transforming attitudes into behavior [3]. Therefore, it is difficult for new vegan movements to be clear and know how to spread their influence across different social groups. The study of veganism has sought to investigate why people become vegan and not to identify consumer segments in order to improve marketing actions [3]. The skill to encourage the purchase of products and services that are organic, ecologically, and environmentally friendly is a competitive advantage and leads to a company's success in this specific business area [4]. However, the literature has failed to reveal the complexity of the relationship between attitudes and beliefs regarding particular foods and an adopted diet [12]. There is a need to understand the stigma in the context of other probable barriers that inhibit meat eaters from going vegetarian [8]. This specific market has not undergone enough studies explaining why people choose this food regime or why not, since some studies mention the difficulty of finding these products, the high prices, and the way to transition from meat diet to vegan diet [13]. To fill these gaps, this study intends to understand the impact of both personal (health awareness and social influence) and moral (environmental concerns and animal welfare) antecedents on attitudes towards vegan products and their effects on involvement with vegan products, as well as their impact on purchase intention and word of mouth (WOM). Idealism is considered to play a role in moderating the proposed relationships. This research is based on two samples, one with 224 Portuguese respondents and another with 356 Brazilian respondents. Even though Portugal and Brazil are related countries, Hofstede identifies several cultural differences, like individualism, masculinity, and indulgence, which may influence attitudes towards veganism and its effects on the behavior of vegans [14].

This paper starts with an introduction that provides a brief overview of the study of the subject, mentioning gaps and the main objectives of the research. Afterwards, the study states the theoretical background and develops the hypotheses and the conceptual model. Section 3 presents the method, while Section 5 introduces the results. The main contributions and limitations of this research are provided in Section 6.

\section{Theoretical Background and Hypothesis Development}

\subsection{Attitudes towards Consumption of Vegan Products}

Veganism supposes different attitudes towards the environment, food, and health and results from a great shift of attitudes from an old, traditional way of life to a healthy, ethical, and natural life [10]. Embracing a vegan lifestyle entails not using animal products or products tested on animals, such as cosmetics and detergents [15]. Understanding consumers' attitudes and behavior towards consumption of vegan products could clarify the decisions made by consumers [16].

Attitudes are predictive of the behavior of consumers, influencing their purchases [16]. Understanding consumers' attitudes and behavior is, therefore, crucial to better deal with markets and customers. The theory of the "attitude toward behavior" explains the decisions taken by consumers and their behavior [16]. Attitude influences thought and choice of a product, framed by consumers' assessment of the product's properties [17]; at the same time, attitude has a significant impact on the purchase choices and decisions of the consumer.

People tend to assess everything —-themselves, others, objects, and surroundings—on a permanent basis, and such assessment is generally influenced by their cultural background. Attitude denotes an individual's positive or negative evaluation of objects [18]. It is a "psychological tendency that is expressed by evaluating a particular entity with some degree of favour or disfavour" [19], and includes emotional and cognitive elements-an emotional element being, for example, love and a cognitive element being, for example, an opinion. Attitude denotes positive or negative feelings towards something (i.e., like and dislike of an object or activity) [20]. Attitude also represents information that a person has about another individual, a particular product, or even an object and is also understood as feelings and beliefs about preparing the purchaser to behave steadily towards it [18]. 
Our assessment of an object, person, or surrounding establishes an attitude, influencing behavior [18] and activating behavioral intentions [16]. The theory of planned behavior [16] acknowledges that motivational factors could have an impact on behavior and attitude, followed by the amount of effort that individuals are willing to spend and how far they would go to carry out an action. Some authors [21] believe that to obtain a good understanding of the factors that have an impact on behavior, it is necessary to verify what determines the individual's attitude. Consequently, attitudes are influenced by three components, all equally important but changeable according to the motivation apropos the individual's attitude towards a specific subject/object. The healthy ingredients of products and their benefits, as well as health choices, are important to obtain a positive attitude towards green products and goods with green packaging [22]. Measuring consumers environmental attitudes and behavior is evocatively one of the most important matters concerning green marketing. Nevertheless, the decision not to eat meat is connected more to attitudes regarding health and animal well-being rather than environmental impacts [23]. Therefore, health awareness and animal welfare are expected to have an impact on attitudes towards consumption of vegan products. Vegans have to stand by their choices and attitudes, since leading such a lifestyle is a crucial characteristic of their being. Vegans have a hard time being themselves in their social circles [23].

\subsection{Understanding Attitudes towards Veganism}

\subsubsection{The role of Health Awareness}

According to the Oxford online dictionary, awareness is "a concern or interest in a particular situation or development" [24]. Therefore, if we add the word "health", we may say that health awareness, put simply, is one's concern about one's health $[25,26]$. Gould [27] conceptualized health awareness into four dimensions. Gould's first dimension is related to one's awareness of the factors that are a risk to one's own health. Second, the dimensions that Gould mentions perceive health awareness as an inner state of mind, thus influencing concerns about health. The third dimension observes the relationship between health awareness and information about health. Lastly, the involvement of health shows how people are focused on participating and contributing to their health. Consumers nowadays focus on well-being and having a healthy diet. Therefore, they are guided by the healthiness of products, and they change their attitudes accordingly. Consequently, some consumers, having found out about the poor nutritional value of some foods, tend to change attitudes and give up certain types of food, even if they enjoy them [28]. It is mentioned that only consumers with health concerns buy hedonic food, where taste and nutrition go hand in hand [29]. The same goes for restaurants, where consumers with greater health awareness tend to look for healthier food [30]. Health awareness is a predictor of healthy attitudes and behavior [27], and this awareness is linked to health information highly influencing one's attitude towards a certain product. Moreover, these consumers associate their healthy life to a healthy diet $[30,31]$. Consumers are certain that their chosen diet influences their health, so with greater health awareness, they tend to have healthier attitudes, like eating well, eating less meat or going vegan, working out, and worrying about the quality of what they eat [28]. Individuals who are more aware about health are therefore self-conscious about their own health. Mai and Hoffmann [32] state that when someone is health conscious, the nutrition of their food is a key factor in their attitudes and purchases.

Accordingly, the following hypothesis is presented:

Hypothesis 1. Health awareness has a positive impact on attitudes towards consumption of vegan products.

\subsubsection{The Role of Environmental Concerns}

Environmental concerns refer to "the degree to which people are aware of environmental problems and support efforts to solve them and/or indicate a willingness to contribute 
personally to their solution" [33]. Environmental concern is the awareness individuals have when talking about environmental matters [34,35], how they are involved emotionally and willing to contribute to the resolution of environmental problems [33,36]. Nevertheless, a research [37] involving individuals from over 40 countries demonstrated that $96 \%$ of them were environmentally conscious, but only $65 \%$ of them would effectively do something for the environment. Environmental concern can also be defined based on attitude, affective, cognitive, and conative dimensions. The affective dimension is related to high environmental awareness, the cognitive dimension refers on having a perfect understanding of the issue, and being willing to act and protect is the conative dimension [34]. There are three ways to understand environmental issues: individuals who are profoundly emotionally moved by environmental problems, individuals who are rational when addressing environmental problems, and lastly, there are individuals who are eager to act [38]. Other studies highlight three types of environmental concerns: egoistic, social-altruistic, and biospheric. The egoistic base of environmental concern is seen when one's own interests are above the interests of others who are not close to oneself, the social-altruistic value is apparent when there is concern for others, and lastly, the biospheric values entail concerns for animals and plants [39]. Environmental concerns have an impact on behavior, purchases, and attitudes [40]. The degree of environmental concern is frequently linked to socio-demographic characteristics, but can also be related to political orientations, ecological value, and belief systems. Some studies refer to the difference between women and men regarding environmental concerns, where women are more concerned about environmental issues than men for the reason that they have different social roles [41]. Individual income also seems to play a role; individuals with higher income demonstrate greater environmental concern [37]. Environmental concern is linked to civic consciousness, which is shown through attitude, recognition, and response to environmental issues [42]. Environmental concerns turn out to be extremely relevant in the consumer's attitude, influencing attitudes and purchasing conduct [43]. Individuals with greater environmental concerns are more willing to change their attitudes and lead eco-friendly lives [44].

Environmental conservation behavior is deep-rooted in individuals who demonstrate environmental concerns. Such concerns are what influence individuals the most to change attitudes and become vegan. Therefore, the following hypothesis is proposed:

Hypothesis 2. Environmental concerns have a positive impact on attitudes towards consumption of vegan products.

\subsubsection{The Role of Animal Welfare}

Animal welfare refers to quality of life that comprises the well-being, life span, feelings, and happiness of animals and their living conditions [45]. In 1944, the Vegan Society was founded in order to stop animal suffering and killing [46]. "Animal welfare" refers to the physical and mental states of an animal in relation to the conditions in which it lives and dies. The "five freedoms" established in 1965 comprise freedom from hunger; freedom from fear and distress; freedom from heat stress or physical discomfort; freedom from pain, injury, and disease; and freedom to express normal patterns of behavior. These five freedoms define society's hopes for animals when under human control [47]. The term "animal welfare" is current in the daily lives of companies, consumers, and politicians, among others, and generally, people believe animals have feelings, such as fear or sadness, and rights. To sum up, animal welfare embodies the respect for the health and behavior of animals [48].

Animal welfare is defined differently by consumers and producers. Consumers are apprehensive about animal welfare, and it has more impact on purchase intention than on environmental concerns. Producers, on the other hand, are increasingly concerned about animal health, such as reducing the pain endured by animals and improving their comfort [49]. Concerns about the welfare of animals, the disapproval of killing them, and animal rights can be the main cause for changing attitudes and becoming a vegetarian 
or vegan [50]. American and European countries tend to change their diet and lifestyle for the sake of animal welfare, whereas the Indian culture fosters vegan eating habits as a result of religious and cultural traditions [20]. Animal welfare is the starting point of the vegan lifestyle, inspiring concerns and attitudes towards vegan products.

Keeping in mind the importance of animal welfare and the vegan lifestyle, the following hypothesis is proposed:

Hypothesis 3. Animal welfare has a positive impact on attitudes towards consumption of vegan products.

\subsubsection{The Role of Social Influence}

Social influence happens when the way of life, actions, thoughts, and interests influence the conduct of others, and their actions change in the company of others [51]. Family and friends influence directly and sincerely through evaluations and attitudes, providing the bases for changes in decisions and attitudes. Individuals can be influenced by the social environment in a number of ways [3]. Social influence has direct and indirect impacts on feelings, views, and attitudes, eventually disturbing behavior. Traditional social influence is related to credibility as well. However, nowadays, influences can come from unknown individuals through social media. No direct contact is necessary for someone to be influenced. This influence disturbs principles, attitudes, and standards [52] and affects purchases [53]. The importance of understanding social influence derives from the fact that it assists in understanding social behavior, consequently supporting decision-making, guiding public opinion, and driving change [54].

As a matter of fact, consumers choose to analyze a product when they are thinking about purchasing it or when thinking about buying or testing it. They get information through numerous channels, social influence being fairly important when analyzing consumers' attitudes and purchase intentions [55]. Social influence is a wide-ranging topic and has strong and steady influence on consumers' actions and attitudes.

The social influence strategies that are studied include social learning, social proof, and social comparison [56]. Social learning occurs when behavior is changed through direct observation and imitation of others [57]. Social proof takes place when someone does not know how to behave and what to say and thus behaves in the same way as the group, assuming the group knows the correct social norms [58]. Social comparison occurs when an individual compares himself/herself with similar others.

There are two types of social influence: informational social influence and normative social influence [59]. Informational social influence involves credibility (i.e., the information given by others is accepted as valid). Normative social influence involves satisfying the group's expectations. In some studies, the expression normative social influence is replaced by informative social influence [60]. Concluding that health behavior is disseminated through social networks, social influence in severe health conditions can help to modify food choices, influence consumption to eliminate negative habits, and direct individuals in positive directions [61].

Regarding veganism, others tend to see an individual who does not eat meat as having a greater sense of virtue and therefore having social influence, inspiring others to become vegan [3,4,12]. People with a strong sense of self-sacrifice are more likely to choose a vegetarian/vegan diet. Thereupon, social influence is identified as a modifier of consumers' choices and behavior, therefore influencing attitudes towards veganism [62]. The present research assumes that the social environment influences attitudes towards a vegan diet. Therefore, the following hypothesis is formed:

Hypothesis 4. Social influence has a positive impact on attitudes towards consumption of vegan products. 


\subsection{Understanding the Effects of Attitudes towards Veganism}

\subsubsection{Involvement with Vegan Products}

Involvement happens when there is interest, connection, commitment, or focus on a specific issue, product, situation that leads to an action [63]. It refers to an understanding and relationship between a person and an aim or subject. Involvement is influenced by principles and benefits [64]. There is higher acceptance of products and services. This happens when there is personal involvement present, and for this reason, involvement can determine the purchase/selection of products. Involvement occurs when an individual searches for information about a product and creates a connection with what is intended to be purchased. It is the perceived relevance of an object/service in relation to values, interests, and needs. It is the main factor in the commitment process of the consumer. Involvement influences decision-making when purchasing. The individual is inclined to purchase a certain product once there is involvement-involvement influenced by personality traits, knowledge, experience [65]. There are several levels of involvement, ranging from high to low involvement that is related to acquisition purpose [66]. High involvement requires more research, effort, consideration, comparison, and evaluation $[67,68]$. Low involvement does not require research, and brand has a major role [69], but when the issue is health, values, and needs [70], or the purchase of quality products [68], involvement is always higher. The resulting involvement is the combination of situational and enduring involvements, where the scope of the cognitive and behavioral complexities influences the purchase process. To summarize, involvement can be understood as the importance given to a product by the consumer's standards and attitudes, likes, and wishes, since people do tend to not purchase an object or service that can have a negative impact on their lives [18]. Involvement is associated with consumer concerns, interests, beliefs, and lifestyle [65], and therefore attitudes. As a result, it can be expected that attitudes towards consumption of vegan products may have an impact on involvement with vegan products. Consequently, the following hypothesis is proposed:

Hypothesis 5. There is a relationship between attitudes towards consumption of vegan products and involvement with vegan products.

\subsubsection{Purchase Intention}

Purchase intention can be understood as the willingness to purchase a product or service. Purchase intention is observed when there is an effort to purchase a product or service and occurs when the provider displays features that meet consumers' needs [70]. Purchase intention is also seen when there is a probability or plan to make a purchase $[18,71,72]$; the stronger the will is, the more likely it is that these products or services will be bought. The predisposition of consumers to satisfy their needs and be active regarding purchases shows that purchase intention is triggered by emotions, which may link them to brands, products, or services [71]. Motivation, needs, or new information can influence purchase intention. Media has influenced the purchase intention process, making it more complex and influenced by several factors [71]. Knowledge about a product is an important factor for purchase intention, as well as information about the products available [73]. Besides product knowledge and information, product image plays an important role as well [74], but familiarity with the product also creates purchase intention, and the more product familiarity there is, the likelier is the purchase intention [75].

Perceived value is a significant factor in consumers' purchase intention and reinforces the willingness to buy and shows a connection between the product and the consumer [70]. Other key aspects influence the purchase intentions of consumers, like price [76], trust [43], and satisfaction [77]. Attitude towards a brand, product, or service has a strong impact on purchase intention and inclination to purchase [78,79].

Engagement with a specific brand, product, or service will influence the choice of buying or not buying something [80]. Consequently, there is greater intention to pur- 
chase [81]. Thus, given the importance of understanding engagement with vegan products and consumer purchase intentions, the following proposal can be considered:

Hypothesis 6. Involvement with vegan products has an impact on purchase intention.

\subsubsection{Word of Mouth}

WOM is defined as "oral, person-to-person communication between a receiver and a communicator whom the receiver notices as being non-commercial, concerning a brand, a product or a service" [82]; information that intends to influence by describing products and services [83], and a collection of information [84]. WOM is one of the first methods of spreading information about goods, "a face to face conversation between consumers about a product or service experience" [85]. WOM is also understood as a way for noncommercial individuals to communicate among themselves without aiming at promoting or benefitting businesses [86]. To sum up, a communication between consumers about a product or service can be defined as word of mouth, a casual conversation between individuals regarding their assessment of products and services [87]. WOM is unquestionably influenced by consumers' choices and involvement [88]. According to the same authors, where there is involvement, there is WOM, which in turn is a way of involving per se, originating communication, and giving information about an idea, product, or service [89]. Therefore, the following hypothesis can be formulated for the WOM variable:

Hypothesis 7. Involvement with vegan products has an impact on WOM.

\subsection{The Moderating Role of Idealism}

The philosophical definition for idealism states that existence is subjective, so accordingly, reality is known through ideas. "Idealism is the opinion that we immediately experience only our own existence but can only infer that of outer things (which inference from effect to cause is in fact uncertain)" [90]. An idealist is someone who believes in ideas and noble feelings. In order to improve society, idealists oppose materialism and believe that what is considered good will succeed [91]. Idealism is "the cherishing or pursuit of high or noble principles, purposes or goals" [92]. Idealism can be understood as an intellectual image of values and standards, seeking to display a person as he or she sees himself or herself. Idealists have principles and morals as important components of their belief system [93]. If people avoid harming others, they are considered idealists, and the more they avoid doing so, the more idealist they are, and these individuals will not act if they know that their action could possibly harm somebody [94]. The idealism of consumers influences their purchase behavior, as these "idealist" consumers have high moral standards and values; moreover, these moral standards influence business environments [95]. In businesses, idealism influences the choices of organizations as regards what products/services to sell and these organizations' work environment itself. The reduction or elimination of meat consumption is due to idealistic features influencing the predisposition to purchase eco-friendly and vegan products, and the higher these moral standards are, the idealism, the more unwilling they are to hurt animals.

The conceptual research model depicts the suggested relationships between the researched constructs. In Figure 1, the model attempts to clarify the set of developed hypotheses. 


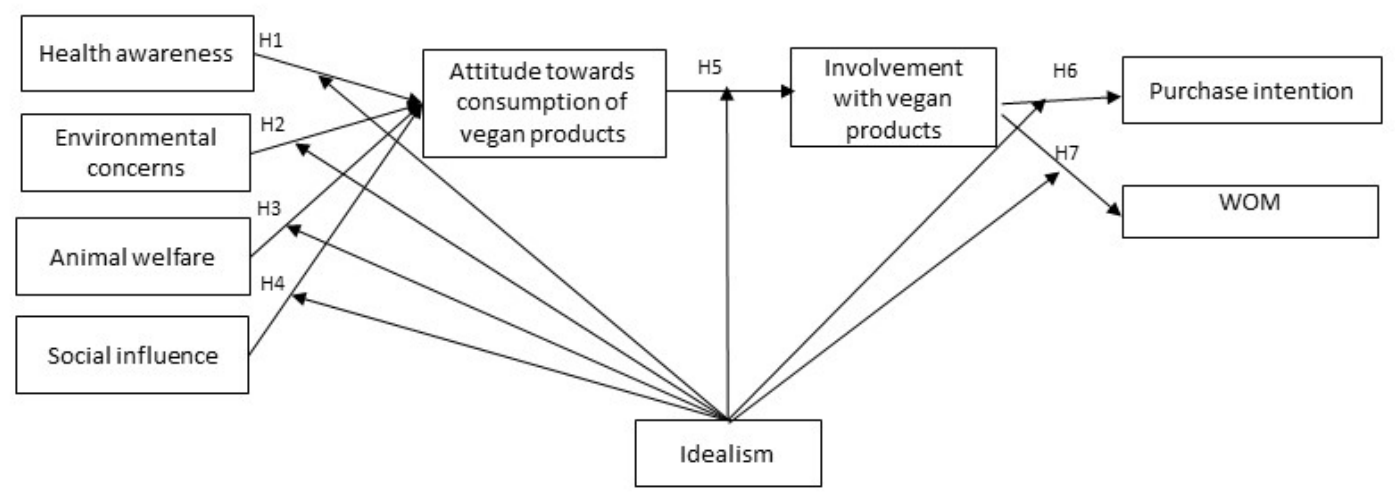

Figure 1. Conceptual model.

\section{Method}

\subsection{Sample and Data Collection}

This study is based on two samples, 224 Portuguese vegans and 356 Brazilian vegans. The sampling was performed by sharing the questionnaire in four vegan groups on Facebook in Portugal with up to a total of 82,500 members (including "Vegetarianos de Portugal," which has 10,000 to 25,000 members) and four groups in Brazil with up to a total of 202,400 members (including "Ogros Veganos," which has 8000 to 170,000 members). We asked a member from each group for permission and help to share our questionnaire and collect the answers. Data collection lasted 2 months, from January to February 2019, and three recalls were made to obtain an acceptable sample. For each parameter, 200 or 5 or 10 cases were agreed as the minimum sample size to perform structural equation modelling [96]. Most of the respondents were female, aged between 18 and 33 years, holding a university degree, employed, and earning a monthly income between $€ 501$ and $€ 1499$ (Table 1).

Table 1. Demographic profile of the respondents.

\begin{tabular}{ccc}
\hline Category & Portugal & Brazil \\
\hline Male & 31 & 39 \\
Female & 193 & 317 \\
Age & & \\
$10-17$ & 6 & 12 \\
$18-25$ & 92 & 126 \\
$26-33$ & 61 & 59 \\
$34-41$ & 31 & 30 \\
Over 41 & 34 & 114 \\
Education & & 242 \\
Secondary school & 87 & 154 \\
Higher education & 137 & 154 \\
Occupation & & 46 \\
Student/student workers & 74 & 164 \\
Employed & 128 & 192 \\
Others & 22 & \\
Household & 115 & 151 \\
1-2 people & 109 & 144 \\
More than 3 people & &
\end{tabular}




\subsection{Measurement}

The questionnaire is based on tested scales, which were translated and adapted from past relevant literature. The questionnaire contained 7 demographic questions and 41 closed questions to measure the proposed concepts. All items were measured on a sevenpoint Likert scale $(1=$ strongly disagree to $7=$ strongly agree $)$. The metrics can be found in Table 2, which identifies the origin of the metrics and the standardized regression weights.

Table 2. Results of confirmatory factor analysis.

\begin{tabular}{|c|c|c|c|}
\hline Construct & Metrics & SRW & CR \\
\hline \multirow{3}{*}{$\begin{array}{c}\text { Attitudes towards } \\
\text { consumption of vegan } \\
\text { products (ATV) } \\
{[97]}\end{array}$} & 1. I am interested in knowing more about vegan products. & 0.901 & - \\
\hline & 2. I would like to consider vegan products as one of my shopping choices. & 0.924 & 34.481 \\
\hline & 3. I have a positive feeling when buying vegan products. & 0.766 & 23.730 \\
\hline \multirow{4}{*}{$\begin{array}{c}\text { Involvement with vegan } \\
\text { products (INV) } \\
{[25]}\end{array}$} & 1. Vegan products are important to me. & 0.929 & - \\
\hline & 2. Vegan products are really interesting to me. & 0.904 & 35.015 \\
\hline & 3. I am concerned about animal issues. & 0.760 & 24.163 \\
\hline & 4. I am very much engaged with vegan products. & 0.630 & 17.767 \\
\hline \multirow{6}{*}{$\begin{array}{l}\text { Health awareness (HA) } \\
\qquad[25]\end{array}$} & 1. I think about my health. & 0.773 & - \\
\hline & 2. I am aware of my health. & 0.877 & 22.543 \\
\hline & 3. I am aware of changes in my health. & 0.800 & 20.261 \\
\hline & 4. I tend to be informed about my health. & 0.826 & 21.064 \\
\hline & 5. I have responsibility for the state of my health. & 0.660 & 16.200 \\
\hline & 6. I monitor my health status daily. & 0.686 & 16.920 \\
\hline \multirow{5}{*}{$\begin{array}{c}\text { Environmental concerns } \\
\text { (EC) } \\
{[98]}\end{array}$} & 1. The balance of nature is very delicate and can be easily changed. & 一 & - \\
\hline & $\begin{array}{l}\text { 2. Human beings, when they interfere with nature, often cause disastrous } \\
\text { consequences. }\end{array}$ & 0.668 & - \\
\hline & 3. Human beings must live in harmony with nature to survive. & 0.770 & 15.378 \\
\hline & 4. Humanity is abusing the environment. & 0.827 & 16.047 \\
\hline & 5. Humanity was not created to dominate the rest of nature. & 0.747 & 15.039 \\
\hline \multirow{7}{*}{$\begin{array}{l}\text { Animal welfare (AW) } \\
\qquad[99]\end{array}$} & 1. Animals must be kept in their natural habitat. & & \\
\hline & 2. It is important for animals to behave naturally. & 0.734 & - \\
\hline & 3. I care about the welfare of animals. & 0.873 & 18.215 \\
\hline & 4. Animals must not suffer. & 0.753 & 16.828 \\
\hline & $\begin{array}{l}\text { 5. The idea of a "natural environment" applies to both domestic and } \\
\text { wild animals. }\end{array}$ & - & - \\
\hline & 6. Companies must think about their profits, but also about animals. & 0.578 & 12.967 \\
\hline & 7. Companies must think about animals as well as their market value and costs. & - & - \\
\hline \multirow{3}{*}{$\begin{array}{l}\text { Social influence (SI) } \\
{[55]}\end{array}$} & 1. My friends often recommend me vegan products. & 0.844 & - \\
\hline & 2. My friends usually go shopping for vegan products with me. & 0.725 & 18.310 \\
\hline & $\begin{array}{l}\text { 3. My friends often share their experiences and knowledge about vegan } \\
\text { products with me. }\end{array}$ & 0.866 & 20.668 \\
\hline \multirow{5}{*}{$\begin{array}{l}\text { Purchase intention (PI) } \\
{[25]}\end{array}$} & 1. I am happy to buy vegan products. & 0.803 & - \\
\hline & 2. I hope to consume vegan products. & 0.856 & 23.679 \\
\hline & 3. I would buy vegan products. & 0.820 & 22.328 \\
\hline & 4. I plan to consume vegan products. & 0.772 & 20.577 \\
\hline & 5. I intend to buy vegan products in the next few days. & 0.650 & 16.566 \\
\hline \multirow{4}{*}{$\begin{array}{l}\text { Word of mouth (WOM) } \\
{[96]}\end{array}$} & 1. I recommend vegan products to many people. & & \\
\hline & 2. I tell my friends about vegan products. & 0.809 & - \\
\hline & 3. I try to spread the benefits of vegan products. & 0.947 & 26.184 \\
\hline & 4. I do a lot of positive advertising for vegan products. & 0.854 & 24.069 \\
\hline
\end{tabular}


Idealism, the moderator, was measured using the scale [100] from Leonidou et al. (2013). Items like "I adhere to universal principles and moral absolutes when making moral judgements" were used [101].

It is important to highlight that to minimize common method variance (CMV), the questionnaire was designed considering some fundamental aspects (e.g., the respondents were not informed about the main topic of the current research, they were assured that their answers would be anonymous and confidential, we informed the respondents that there were no right or wrong answers, and we stressed that their participation was very important for this research, etc.) [102]. Harman's single factor test and a common latent factor analysis were performed to identify the common variance [102]. Harman's test, carried out in SPSS 25.0, showed that any factor could explain more than $20.77 \%$ of the variance, and there were seven factors with eigenvalues greater than one explaining $71.338 \%$ of the total variance [103]. In addition, a confirmatory factor analysis was done, limiting all items of the model to load on a common single factor [102]. The resulting fit indices show that the model did not provide an acceptable fit (chi-square/degrees of freedom $(\mathrm{X} 2 / \mathrm{Df})=14.864$; incremental fit index (IFI) = 0.453; Tucker-Lewis index (TLI) $=0.414$; comparative fit index $(C F I)=0.452$; root mean square error of approximation $($ RMSEA $)=0.155)$, so the common method bias does not seem to be a problem.

A confirmatory factor analysis was used to measure the psychometric properties of the scales and the measurement model fit [104] using Amos 25. The end model shows a good fit (IFI = 0.925; TLI = 0.917; CFI = 0.924; $\mathrm{RMSEA}=0.058 ; \mathrm{X} 2 / \mathrm{Df}=2.966$ ) [95]. Table 3 presents the bivariate correlations and Cronbach's alpha, composite reliabilities, and average variances extracted that support validity and reliability analyses. Composite reliability (CR) and the average variance extracted (AVE) were computed. All scales showed values above 0.7 on CR and above 0.5 on AVE, which are in line with the recommendations [96]. Discriminant validity is supported by the fact that all bivariate correlations between the constructs are significantly smaller than 1 , and the squared correlations calculated for each pair of constructs are always smaller than the variance extracted for the corresponding constructs [97], thereby confirming the discriminant validity (Table 3).

Table 3. Bivariate correlations, Cronbach's alpha, composite reliabilities, and average variances extracted.

\begin{tabular}{|c|c|c|c|c|c|c|c|c|c|c|c|}
\hline Constructs & SD & HA & EC & AW & SI & ATV & INV & PI & WOM & AVE & CR \\
\hline HA & 0.841 & 0.888 & & & & & & & & 0.599 & 0.899 \\
\hline EC & 0.377 & 0.177 & 0.821 & & & & & & & 0.571 & 0.841 \\
\hline AW & 0.348 & 0.028 & 0.218 & 0.805 & & & & & & 0.550 & 0.828 \\
\hline SI & 1.709 & 0.080 & 0.181 & 0.049 & 0.852 & & & & & 0.663 & 0.854 \\
\hline ATV & 0.638 & 0.087 & 0.199 & 0.237 & 0.098 & 0.885 & & & & 0.751 & 0.900 \\
\hline INV & 0.723 & 0.146 & 0.251 & 0.212 & 0.097 & 0.591 & 0.872 & & & 0.684 & 0.885 \\
\hline PI & 0.613 & 0.108 & 0.240 & 0.229 & 0.094 & 0.502 & 0.504 & 0.873 & & 0.644 & 0.887 \\
\hline WOM & 0.900 & 0.105 & 0.183 & 0.138 & 0.269 & 0.435 & 0.409 & 0.377 & 0.899 & 0.760 & 0.904 \\
\hline
\end{tabular}

Notes: SD—standard deviation; diagonal in bold—Cronbach's alpha; CR—composite reliability; AVE—average variance extracted; HA— Health awareness; EC—Environmental concerns; AW—Animal welfare; SI—Social influence; ATV—Attitudes towards consumption of vegan products; INV—-Involvement with vegan products; PI—Purchase intention; WOM-Word of mouth.

\section{Results}

Amos 25 was used to perform structural equation modelling (SEM) and the hypothesis test. Covariance-based structural equation modelling is a suitable technique to perform confirmatory factor analysis and SEM when we have a good sample size (more than 200) and multivariate data normality [105]. The final model shows a good fit (IFI $=0.925$; $\mathrm{TLI}=0.917 ; \mathrm{CFI}=0.924 ; \mathrm{RMSEA}=0.058 ; \mathrm{X} 2 / \mathrm{Df}=2.966)$. A multigroup analysis was performed to test the moderation effects of idealism. We divided the sample in two groups based on average: the high-idealism group (above average), with 357 respondents, and the low-idealism group (below average), with 223 respondents. Furthermore, group nationality analysis was performed: 224 Portuguese respondents and 356 Brazilian respondents. 
Metric invariance was tested, and a CFI difference below 0.01 was found in both models, supporting the expected metric invariance [106].

Table 4 presents the overall results for hypothesis testing, the idealism moderation effects, and the comparison between countries. H1 $(\mathrm{R}=0.064 ; p>0.05)$ and H4 $(\mathrm{R}=0.061$; $p>0.05)$ are not supported, showing that health awareness and social influence do not affect attitude towards veganism (ATV). H2 $(\mathrm{R}=0.149 ; p<0.01)$ and H3 $(\mathrm{R}=0.205 ; p<0.01)$ are supported, showing that environmental concerns and animal welfare are the drivers of ATV. H5 ( $\mathrm{R}=0.858 ; p<0.01)$, H6 ( $\mathrm{R}=0.865 ; p<0.01)$, and H7 $(\mathrm{R}=0.432 ; p<0.01)$ support the hypothesis that ATV may influence involvement with vegan products, purchase intention, and WOM.

Table 4. Results.

\begin{tabular}{|c|c|c|c|c|c|c|c|c|c|c|}
\hline & \multirow{2}{*}{\multicolumn{2}{|c|}{$\begin{array}{l}\text { General } \\
(n=580)\end{array}$}} & \multirow{2}{*}{\multicolumn{2}{|c|}{$\begin{array}{c}\text { High Idealism } \\
(n=357)\end{array}$}} & \multirow{2}{*}{\multicolumn{2}{|c|}{$\begin{array}{c}\text { Low Idealism } \\
\qquad(n=223)\end{array}$}} & \multirow{2}{*}{\multicolumn{2}{|c|}{$\begin{array}{l}\text { Portugal } \\
(n=224)\end{array}$}} & \multirow{2}{*}{\multicolumn{2}{|c|}{$\begin{array}{c}\text { Brazil } \\
(n=356)\end{array}$}} \\
\hline & & & & & & & & & & \\
\hline & SRW & $p$ & SRW & $p$ & SRW & $p$ & SRW & $p$ & SRW & $p$ \\
\hline $\begin{array}{c}\text { H1 } \\
\text { Health awareness } \rightarrow \text { ATV }\end{array}$ & 0.064 & NS & 0.099 & * & -0.009 & NS & 0.023 & NS & 0.055 & NS \\
\hline $\begin{array}{c}\mathrm{H} 2 \\
\text { Environmental concerns } \\
\rightarrow \mathrm{ATV}\end{array}$ & 0.149 & $* *$ & 0.095 & NS & 0.169 & * & 0.228 & $* *$ & 0.124 & $*$ \\
\hline $\begin{array}{c}\text { H3 } \\
\text { Animal welfare } \rightarrow \text { ATV }\end{array}$ & 0.205 & $* *$ & 0.173 & $* *$ & 0.226 & $* *$ & 0.348 & $* *$ & 0.117 & $*$ \\
\hline $\begin{array}{c}\text { H4 } \\
\text { Social influence } \rightarrow \text { ATV }\end{array}$ & 0.061 & NS & 0.072 & NS & 0.041 & NS & 0.057 & NS & 0.059 & NS \\
\hline $\begin{array}{c}\text { H5 } \\
\mathrm{ATV} \rightarrow \mathrm{IVP}\end{array}$ & 0.858 & $* *$ & 0.852 & $* *$ & 0.873 & $* *$ & 0.926 & $* *$ & 0.812 & $* *$ \\
\hline IVP $\rightarrow$ Purchase & 0.865 & $* *$ & 0.939 & $* *$ & 0.794 & $* *$ & 0.959 & $* *$ & 0.802 & $* *$ \\
\hline $\begin{array}{c}\text { H7 } \\
\text { IVP } \rightarrow \text { WOM }\end{array}$ & 0.432 & $* *$ & 0.471 & $* *$ & 0.35 & $* *$ & 0.452 & $* *$ & 0.425 & $* *$ \\
\hline
\end{tabular}

Notes: (1) p- significance; (2) two-tailed test: ${ }^{* *} p<0.01 ; * p<0.05$; n.s.—not significant $(p>0.05)$; (3) ATV—attitude towards veganism; IVP-involvement with vegan products; NS—not significant.

\section{Discussion}

Environmental concerns are expected to influence or predict an individual's attitudes towards a vegan diet, establishing a relationship with ATV [44]. At the same time, attitudes towards animal welfare are expected to have an impact on one's attitudes towards nonanimal food and rejection of animal-based products [50]. Our results support these assumptions, showing how individual ideology may influence the individual's attitudes towards veganism. On the contrary, individual issues like one's health and social influence do not seem to have an impact on the attitudes of vegans. In fact, veganism seems not to be a matter of individual convenience or social norms. Veganism is a matter of beliefs and attitudes towards nature, animals, and the environment. What drives human attitude towards veganism are not individual factors, but essentially questions of ideological nature [107] that address the engagement of people with nature and respect for animal life. The need to reduce meat consumption is ethically justified [108]. Individuals choose to become vegan based on principles like animal welfare and the environment and readjust their lifestyle because they are concerned about the well-being of others [94] and are predisposed to changing their attitudes and behavior. Vegans are concerned about ethical factors, connecting their belief system with attitudes, linking ideals and the consumption of vegan products [109].

$\mathrm{H} 5, \mathrm{H} 6$, and $\mathrm{H7}$ are supported, showing that ATV can influence involvement with vegan products, purchase intention, and WOM. According to the literature [67], attitude 
represents individuals' assessment of a product and their position towards a product, thus influencing involvement. Apparently, based on our results, individuals who develop a positive attitude towards consumption of vegan products are more involved with vegan products. At the same time, highly ecologically committed individuals seek to buy according to their connection with a product, and purchase intentions rise after individuals perceive the value of a product fitting their vegan lifestyle $[70,79]$. Because vegans are deeply involved in this way of life, buying requires intense research and planning in order to purchase adequate vegan products [72]. Furthermore, based on our results, individuals who are engaged in vegan diet and eco-friendly lifestyle are more likely to buy vegan products. WOM is a form of involvement influenced by individuals' choices and attitudes towards products $[89,110]$. Apparently, based on our results, individuals who become involved with vegan products are more likely to spread their opinions to others.

Aspects related to moderation show that, in fact, idealism seems to affect the way the environment and animal welfare have an impact on attitudes, and it appears that it is among individuals with lower idealism that these impacts are greater (i.e., the pressure to increase respect for nature and the environment is translated into a growing trend towards veganism). This is particularly evident in people with lower idealism, because, apparently, people with higher idealism no longer need this awareness and this effort. In contrast, we realize in $\mathrm{H} 5, \mathrm{H} 6$, and $\mathrm{H} 7$ that, in fact, it is idealism that turns attitudes and involvement into behavior, meaning that individuals with higher idealism are those who go beyond attitudes and are more prone to convert it into purchasing decisions and commitment to others by disseminating a positive WOM. As for nationality differences, we found that, among the Portuguese respondents, the impacts of the environment (H2) and animal welfare $(\mathrm{H} 3)$ were greater. In $\mathrm{H} 6$ and $\mathrm{H} 7$, the Portuguese respondents demonstrated once more that attitudes turn easily into behavior. With regard to the effects of the differences between Portugal and Brazil, we found that in all cases, it was in Portugal that the effects were greatest. These results may be explained by some differences between the countries. According to Hofstede Insights [14], both countries are classified as collectivist countries. Therefore, the groups easily exchanged views and communicated about what is believed to be correct. However, the slight difference between the countries may explain attitudes turning into behavior due to loyalty to the group, which influences lifestyles and choices. According to studies from Hofstede [14], indulgence is higher in Brazil. Portuguese are pessimistic by nature, and they feel controlled by social norms while believing that something that is joyful in their life is wrong to some extent. On the other hand, based on the same studies, Brazilians are more permissive, easygoing, and impetuous, and they appreciate life. These cultural features probably explain the variance in the results. Portuguese are less competitive, more compromised, respecting fairness, solidarity and value, and concerned about quality of life and the community, while Brazilians are more competitive and focused on winning [14]. Such differences may also explain the results.

\section{Contributions and Limitations}

\subsection{Theoretical Contributions}

Vegan lifestyle features not consuming any animal products or animal-tested products. The number of people who opt for this lifestyle is rapidly increasing all over the world. However, the literature shows that little research has been produced on how it has an impact on attitudes towards the consumption of vegan products. The present study contributes to the awareness and dissemination of vegan products. Our research provides three major contributions: (1) the first contribution is based on the comparison between variables of a more individual nature, such as health awareness and social influence, and variables of a more ideological nature, namely, environmental awareness and animal welfare; (2) the research provides a more comprehensive outlook on attitudes and involvement, investigating antecedents and consequents and establishing a chain of effects between determinants and outcomes of vegan attitudes; (3) and this study introduces the moderating role of idealism, creating a specific individual context that may influence the impact of 
attitudes/involvement on purchase intentions and WOM. Previous studies supported the idea that health awareness and social influence [3] lead individuals to veganism, but our results show otherwise. Additionally, this research introduces the effects of national culture by comparing Brazilian and Portuguese vegans.

\subsection{Practical and Policy Implications}

In addition to making academic contributions, this study demonstrates that the vegan philosophy lifestyle is especially related to animal welfare and environmental concerns. On the other hand, more individual issues, like health issues, do not have an impact on vegan consumers. The findings show that emotional concerns and ideological issues motivate individuals to become vegan, and concern for animals' well-being and the environment are the drivers toward adopting veganism. Veganism is about animal protection, the choice to live as much as possible with the absence of animal products, and the abolishment of meat eating and use of animal products of any kind in the day-to-day life. The study may help vegan movements, animal protection movements, and public policies to be more efficient and influential in society and win more supporters to their cause. Perceived health and food awareness plans should have a special place in schools and be part of citizenship programs in order to display the key determinants of issues involving animals and nature protection [111]. Recognition and support for vegan diets and lifestyles will lead to a major understanding of the importance of protecting animal life, the climate, and nature [112].

At the same time, the study helps marketing directors to understand how to reach vegan consumers and how to transform their businesses, reacting and creating value propositions that answer to these clients' needs. By understanding motivations and emotions, marketing strategies may by crafted in order to answer these more ideological consumers. The study displays the path that consumers are taking, for both vegans and nonvegans, opening access to new business opportunities and improving existing ones by understanding all those who want to spread respect for animals and nature and for ethical behavior in consumption. Therefore, in terms of practical implications, the moderating effects stated in this study suggest that marketing directors should follow not consumers' individual factors but those with ideological nature, appealing to a more ethical product and marketing strategy.

\subsection{Limitations and Future Research Directions}

This is a cross-sectional study that does not allow inference of causality, as it shows relationships but does not demonstrate causality among the variables; its ability to detect strict causality between variables is restricted. The proposed model should be replicated in other countries in order to understand behavior and attitudes towards vegan products, since cultural aspects seem to be relevant. The vegan movement will gain from studies that try to understand intentions to adopt this lifestyle. Consequently, this research seeks to address the individual from both vegan and consumer perspectives, taking into account beliefs and intentions. The marketing area stands to gain from this understanding and should be able to analyze and design products and services for these consumers, fostering the development of new products and identifying those that already exist.

As for recommendations for future research, the model could be tested analyzing the effects of gender and introducing variables like ethical consumption, personality traits, sensitivity, and religion, which could be relevant drivers of vegan attitudes.

Author Contributions: I.M.--Introduction; Theoretical Background and Hypothesis Development and discussion. A.C.-Abstract; Hypothesis Development; Contributions and Limitations; supervision and final revision C.M.B.-Method and Results, editing and final revision. All authors have read and agree to the published version of the manuscript.

Funding: This work has been funded by national funds through FCT—Fundação para a Ciência e a Tecnologia, I.P., Project UIDB/05037/2020.

Conflicts of Interest: The authors declare no conflict of interest. 


\section{References}

1. Earle, M.; Hodson, G. What's your beef with vegetarians? Predicting anti-vegetarian prejudice from pro-beef attitudes across cultures. Pers. Individ. Differ. 2017, 119, 52-55. [CrossRef]

2. Janssen, M.; Busch, C.; Rödiger, M.; Hamm, U. Motives of consumers following a vegan diet and their attitudes towards animal agriculture. Appetite 2016, 105, 643-651. [CrossRef] [PubMed]

3. Wescombe, N.J. Communicating Veganism: Evolving Theoretical Challenges to Mainstreaming Ideas. Stud. Media Commun. 2019, 7, 1-8. [CrossRef]

4. Raggiotto, F.; Mason, M.C.; Moretti, A. Religiosity, materialism, consumer environmental predisposition. Some insights on vegan purchasing intentions in Italy. Int. J. Consum. Stud. 2018, 42, 613-626. [CrossRef]

5. The Vegan Society. Available online: https://www.vegansociety.com/news/media/statistics (accessed on 25 May 2019).

6. The Vegan Society. Available online: https://www.vegansociety.com/go-vegan/definition (accessed on 25 May 2019).

7. Sneijder, P.; Te Molder, H. Normalizing ideological food choice and eating practices. Identity work in online discussions on veganism. Appetite 2009, 52, 621-630. [CrossRef]

8. Rosenfeld, D.L.; Tomiyama, A.J. Taste and health concerns trump anticipated stigma as barriers to vegetarianism. Appetite 2020, 144, 104469. [CrossRef]

9. Sobal, J.; Bisogni, C.A.; Jastran, M. Food Choice Is Multifaceted, Contextual, Dynamic, Multilevel, Integrated, and Diverse. Mind Brain Educ. 2014, 8, 6-12. [CrossRef]

10. Greenebaum, J. Vegans of color: Managing visible and invisible stigmas. Food Cult. Soc. 2018, 21, 680-697. [CrossRef]

11. Han, H.; Hsu, L.T.; Sheu, C. Application of the Theory of Planned Behavior to green hotel choice: Testing the effect of environmental friendly activities. Tour. Manag. 2010, 31, 325-334. [CrossRef]

12. de Gavelle, E.; Davidenko, O.; Fouillet, H.; Delarue, J.; Darcel, N.; Huneau, J.F.; Mariotti, F. Self-declared attitudes and beliefs regarding protein sources are a good prediction of the degree of transition to a low-meat diet in France. Appetite 2019, $142,104345$. [CrossRef]

13. Phua, J.; Jin, S.; Kim, J.J. The roles of celebrity endorsers' and consumers' vegan identity in marketing communication about veganism. J. Mark. Commun. 2019, 26, 813-835. [CrossRef]

14. Hofstede Insights. Available online: https://www.hofstede-insights.com/country-comparison/brazil,portugal/?fbclid=IwAR1 mlOuaAAIujbTaGRKpO0FieASANtmSR2ZRbO8nIneKxWhC5_Ck81hf7Qw (accessed on 17 March 2019).

15. Son, G.Y.T.; Bulut, M. Vegan and vegetarianism as a lifestyle. Int. J. Hum. Sci. 2016, 13, 830-843.

16. Ajzen, I. The theory of planned behaviour. Organ. Behav. Hum. Decis. Process. 1991, 50, 179-211. [CrossRef]

17. Zablocki, A.; Makri, K.; Houston, M.J. Emotions within Online Reviews and their Influence on Product Attitudes in Austria, USA and Thailand. J. Interact. Mark. 2019, 46, 20-39. [CrossRef]

18. Fishbein, M.; Ajzen, I. Belief, Attitude, Intention, and Behavior: An Introduction to Theory and Research; Addison-Wesley Publishing Company: Boston, MA, USA, 1975.

19. Eagly, A.H.; Chaiken, S. The Psychology of Attitudes; Harcourt Brace Jovanovich College Publisher: San Diego, CA, USA, $1993 ;$ p. 1.

20. Del Hawkins, I.; Best, R.J.; Coney, K.A. Consumer Behaviour: Building Market Strategy, 9th ed.; Mcgraw-Hill/Irwin: New York, NY, USA, 2004.

21. Ajzen, I.; Fishbein, M. Understanding Attitudes and Predicting Social Behaviour; Prentice-Hall: Upper Saddle River, NJ, USA, 1980.

22. Jaiswal, D.; Kant, R. Green purchasing behaviour: A conceptual framework and empirical investigation of Indian consumers. J. Retail. Consum. Serv. 2018, 41, 60-69. [CrossRef]

23. Rosenfeld, D.L.; Burrow, A.L. Development and validation of the dietarian identity questionnaire: Assessing self-perceptions of animal-product consumption. Appetite 2018, 127, 182-194. [CrossRef]

24. Oxford Advanced Learner's Dictionary. Available online: https://www.oxfordlearnersdictionaries.com/definition/english/ awareness?q=awareness (accessed on 24 April 2019).

25. Teng, C.-C.; Lu, C.-H. Organic food consumption in Taiwan: Motives, involvement, and purchase intention under the moderating role of uncertainty. Appetite 2016, 105, 95-105. [CrossRef]

26. Fehér, A.; Gazdecki, M.; Véha, M.; Szakály, M.; Szakály, Z. A Comprehensive Review of the Benefits of and the Barriers to the Switch to a Plant-Based Diet. Sustainability 2020, 12, 4136. [CrossRef]

27. Gould, S.J. Health consciousness and health behavior: The application of a new health consciousness scale. Am. J. Prev. Med. 1990, 6, 228-237. [CrossRef]

28. Szakály, Z.; Szente, V.; Kövér, G.; Polereczki, Z.; Szigeti, O. The influence of lifestyle on health behavior and preference for functional foods. Appetite 2012, 58, 406-413. [CrossRef]

29. Loebnitz, N.; Grunert, K.G. Impact of self-health awareness and perceived product benefits on purchase intentions for hedonic and utilitarian foods with nutrition claims. Food Qual. Prefer. 2018, 64, 221-231. [CrossRef]

30. Sualakamala, S.; Huffman, L. Value negotiation for healthy food selection in restaurants. J. Culin. Sci. Technol. 2010, 8, 242-256. [CrossRef]

31. Bryant, C.J. We Can't Keep Meating Like This: Attitudes towards Vegetarian and Vegan Diets in the United Kingdom. Sustainability 2019, 11, 6844. [CrossRef]

32. Mai, R.; Hoffmann, S. Taste lovers versus nutrition fact seekers: How health consciousness and self-efficacy determine the way consumers choose food products. J. Consum. Behav. 2012, 11, 316-328. [CrossRef] 
33. Dunlap, R.; Jones, R. Environmental Concern: Conceptual and Measurement Issues. In Handbook of Environmental Sociology; Dunlap, R., Michelson, W., Eds.; Greenwood Press: London, UK, 2002; p. 484.

34. Franzen, A.; Vogl, D. Two Decades of Measuring Environmental Attitudes: A Comparative Analysis of 33 Countries. Glob. Environ. Chang. 2013, 23, 1001-1008. [CrossRef]

35. Cruz, S.M. The relationships of political ideology and party affiliation with environmental concern: A meta-analysis. J. Environ. Psychol. 2017, 53, 81-91. [CrossRef]

36. Lawo, D.; Esau, M.; Engelbutzeder, P.; Stevens, G. Going Vegan: The Role(s) of ICT in Vegan Practice Transformation. Sustainability 2020, 12, 5184. [CrossRef]

37. Inglehart, R. Public Support for Environmental Protection: Objective Problems and Subjective Values in 43 Societies. PS Political Sci. Politics 1995, 28, 57-72. [CrossRef]

38. Maloney, M.P.; Ward, M.P.; Braucht, G.N. A revised scale for the measurement of ecological attitudes and knowledge. Am. Psychol. 1975, 30, 787-790. [CrossRef]

39. Dietz, T.; Fitzgerald, A.; Shwom, R. Environmental values. Annu. Rev. Environ. Resour. 2005, 30, 335-372. [CrossRef]

40. Pagiaslis, A.; Krontalis, A.K. Green consumption behavior antecedents: Environmental concern, knowledge, and beliefs. Psychol. Mark. 2014, 31, 335-348. [CrossRef]

41. Marquart-Pyatt, S.T. Contextual influences on environmental concerns cross-nationally: A multilevel investigation. Soc. Sci. Res. 2012, 41, 1085-1099. [CrossRef] [PubMed]

42. Russell, W.; Joan, W. Environmental concern: The development of a measure. Environ. Behav. 1978, 10, 3-15.

43. Konuk, F.A.; Rahman, S.U.; Salo, J. Antecedents of green behavioral intentions: A cross-country study of Turkey, Finland and Pakistan. Int. J. Consum. Stud. 2015, 39, 586-596. [CrossRef]

44. Wang, Z.; Zhao, C.; Yin, J.; Zhang, B. Purchasing intentions of Chinese citizens on new energy vehicles: How should one respond to current preferential policy? J. Clean. Prod. 2017, 161, 1000-1010. [CrossRef]

45. Wolf, C.A.; Tonsor, G.T. Cow welfare in the US dairy industry: Willingness-to Pay and willingness-to-supply. J. Agric. Resour. Econ. 2017, 42, 164-179.

46. The Vegan Society. Available online: https://www.vegansociety.com/about-us/history (accessed on 25 May 2019).

47. OIE. Introduction to the Recommendations for Animal Welfare. Paris: World Organisation for Animal Health. Available online: https: / / www.oie.int/en/animal-welfare/animal-welfare-at-a-glance/ (accessed on 27 June 2019).

48. Greenebaum, J.B. Veganism, identity and the quest for authenticity. Food Cult. Soc. 2012, 15, 129-144. [CrossRef]

49. Ventura, B.A.; von Keyserlingk, M.A.; Weary, D.M. Animal welfare concerns and values of stakeholders within the dairy industry. J. Agric. Environ. Ethics 2015, 28, 109-126. [CrossRef]

50. Petti, A.; Palmieri, B.; Vadalà, M.; Laurino, C. Vegetarianism and veganism: Not only benefit but also gaps. A review. Prog. Nutr. 2017, 19, 229-242.

51. Markowski, K.L.; Roxburgh, S. If I became a vegan, my family and friends would hate me: Anticipating vegan stigma as a barrier to plant-based diets. Appetite 2019, 135, 1-9. [CrossRef]

52. Tan, G.W.-H.; Ooi, K.-B. Gender and age: Do they really moderate mobile tourism shopping behavior? Telemat. Inform. 2018, 35, 1617-1642. [CrossRef]

53. Ishibashia, K.; Yada, K. Analysis of social influence on in-store purchase behavior by using ecological system of ants. Procedia Comput. Sci. 2019, 159, 2162-2171. [CrossRef]

54. Peng, S.; Yang, A.; Cao, L.; Yu, S.; Xie, D. Social influence modelling using information theory in mobile social networks. Inf. Sci. 2017, 379, 146-159. [CrossRef]

55. Varshneya, G.; Pandey, S.K.; Das, G. Impact of Social Influence and Green Consumption Values on Purchase Intention of Organic Clothing: A Study on Collectivist Developing Economy. Glob. Bus. Rev. 2017, 18, 478-492. [CrossRef]

56. Stibe, A.; Larson, K. Persuasive Cities for Sustainable Wellbeing: Quantified Communities. In International Conference on Mobile Web and Information Systems; Springer: Cham, Switzerland, 2016; pp. 271-282.

57. Stibe, A.; Oinas-Kukkonen, H. User engagement in feedback sharing through social influence. In The Evolution of the Internet in the Business Sector: Web 1.0 to Web 3.0; IGI Global Book Series Advances in E-business; IGI Global: Hershey, PA, USA, 2015; pp. 234-257.

58. Rao, H.; Greve, H.R.; Davis, G.F. Fool's gold: Social proof in the initiation and abandonment of coverage by Wall Street analysts. Adm. Sci. Q. 2001, 46, 502-526. [CrossRef]

59. Hogg, M.A.; Abrams, D.; Otten, S.; Hinkle, S. The social identity perspective: Intergroup relations, self-conception, and small groups. Small Group Res. 2004, 35, 246-276. [CrossRef]

60. Kuan, K.K.; Zhong, Y.; Chau, P.Y. Informational and normative social influence in group-buying: Evidence from self-reported and EEG data. J. Manag. Inf. Syst. 2014, 30, 151-178. [CrossRef]

61. Polivy, J.; Pliner, P. She got more than me. Social comparison and the social context of eating. Appetite 2015, 86, 88-95. [CrossRef]

62. Seyfang, G. Ecological citizenship and sustainable consumption: Examining local organic food networks. J. Rural Stud. 2006, 22, 383-395. [CrossRef]

63. Richins, M.L.; Bloch, P.H. After the New wears off: The Temporal Context of Product Involvement. J. Consum. Res. 1986, 13, 280-285. [CrossRef] 
64. Ghali, Z. The Antecedents of the Consumer Purchase Intention: Sensitivity to Price and Involvement in Organic Product: Moderating Role of Product Regional Identity. Trends Food Sci. Technol. 2019, 16, 126-136.

65. Baldini, A.P.T.; Ponchio, M.C. Avaliação do processo de compra de alto envolvimento: Aplicação do Consumer Styles Inventory ao mercado brasileiro de veículos comerciais leves. Rev. Adm. Unimep 2018, 16, 107-131.

66. Park, S.C.; Keil, M. The moderating effects of product involvement on escalation behavior. J. Comput. Inf. Syst. 2019, 59, 218-232. [CrossRef]

67. Kim, S.; Lee, S.K.; Jeong, J.; Moon, J. The effect of agritourism experience on consumers' future food purchase patterns. Tour. Manag. 2019, 70, 144-152. [CrossRef]

68. Rokonuzzaman, M.; Harun, A.; Al-Emran, M.; Prybutok, V.R. An investigation into the link between consumer's product involvement and store loyalty: The roles of hopping value goals and information search as the mediating factors. J. Retail. Consum. Serv. 2020, 52, 101933. [CrossRef]

69. Jeseviciute-Ufartiene, L. Consumer involvement in the purchasing process: Consciousness of the choice. Econ. Cult. 2019, 16, 126-135. [CrossRef]

70. Dodds, W.B.; Monroe, K.B.; Grewal, D. Effects of price, brand and store information on buyers' product evaluations. J. Mark. Res. 1991, 28, 307-319.

71. Luo, M.M.; Chen, J.-S.; Chin, R.K.H.; Liu, C.-C. An examination of the effects of virtual experiential marketing on online customer intentions and loyalty. Serv. Ind. J. 2011, 31, 2163-2191. [CrossRef]

72. Wu, P.C.S.; Yeh, G.Y.-Y.; Hsiao, C.-R. The effect of store image and service quality on brand image and purchase intention for private label brands. Australas. Mark. J. 2011, 19, 30-39. [CrossRef]

73. Chen, K.; Deng, T. Research on the Green Purchase Intentions from the Perspective of Product Knowledge. Sustainability 2016, 8 , 943. [CrossRef]

74. Imelia, R.; Ruswanti, E. Factors affecting purchase intention of electronic house wares in Indonesia. Int. J. Bus. Manag. Invent. 2017, 6, 37-44.

75. Liu, D.; Guo, X. Can trust and social benefit really help? Empirical examination of purchase intentions for wearable devices. Inf. Dev. 2016, 33, 43-56. [CrossRef]

76. Wu, J.; Hsu, C. Critical success factors for improving decision quality on collaborative design in the IC supply chain. J. Qual. 2009, $16,95-108$.

77. Ilie, M.; Moraru, A.D.; Silvia, G.M. The Hierarchical Determination of Customer Satisfaction with Banking Services Using an Artificial Neural Network. Transform. Bus. Econ. 2017, 16, 401-421.

78. Li, Q.; Curtis, K.R.; Mccluskey, J.J.; Wahl, T.I. Consumer attitudes toward genetically modified foods in Beijing, China. J. Agrobiotechnol. Manag. Econ. 2002, 5, 145-152.

79. Hsu, C.-L.; Chang, C.-Y.; Yansritakul, C. Exploring purchase intention of green skincare products using the theory of planned behavior: Testing the moderating effects of country of origin and price sensitivity. J. Retail. Consum. Serv. 2017, 34, 145-152 [CrossRef]

80. Holmes, J.H.; Lett, J.D. Product sampling and word of mouth. J. Advert. Res. 1977, 17, 35-40.

81. Wang, Y.C.; Wu, P.C.S. The influences of electronic word-of-mouth message appeal and message source credibility on brand attitude. Asia Pac. J. Mark. Logist. 2011, 23, 448-472.

82. Arndt, J. Word-of-Mouth Advertising and of Informal Communication. In Risk Taking and Information Handling in Consumer Behavior; Cox, D.F., Ed.; Division of Research, Graduate School of Business Administration, and Harvard University: Boston, MA, USA, 1967; p. 3.

83. Westbrook, R.A. Product/consumption based affective responses and post-purchase processes. J. Mark. Res. 1987, 24, 258-270. [CrossRef]

84. Wee, C.H.; Lim, S.L.; Lwin, M. General Perception of Word-of-Mouth Communication as a Source of Information: The Case of Singapore. Asia Aust. Mark. J. 1995, 3, 5-36. [CrossRef]

85. Sen, S.; Lerman, D. Why are you telling me this? An examination into negative consumers reviews on the web. J. Interact. Mark. 2007, 21, 76-94. [CrossRef]

86. Mishra, P.; Bakshi, M.; Singh, R. Impact of consumption emotions on WOM in movie consumption: Empirical evidence from emerging markets. Australas. Mark. J. 2016, 24, 59-67. [CrossRef]

87. Zhang, L.; Li, D.; Cao, C.; Huang, S. The influence of greenwashing perception on green purchasing intentions: The mediating role of green word-of-mouth and moderating role of green concern. J. Clean. Prod. 2018, 187, 740-750. [CrossRef]

88. Houston, M.J.; Rothschild, M.L. Conceptual and Methodological Perspectives on Involvement. Res. Front. Mark. Dialogues Dir. 1978, 28, 307-319.

89. Maklan, S.; Klaus, P. Customer Experience: Are We Measuring the Right Things. Int. J. Mark. Res. 2011, 53, 771-792. [CrossRef]

90. Kant, I. Notes and Fragments; Cambridge University Press: Cambridge, UK, 2010; p. 294.

91. Pablé, A. Radical indeterminacy, idealism, realism: Benedetto Croce vs. Roy Harris. Lang. Commun. 2018, 61, 46-57. [CrossRef]

92. Random House. Random House Webster's Dictionary, 4th ed.; Ballantine Books: New York, NY, USA, 2001; p. X.

93. Sarnowski, J. "Self-Preservation": Identity, Idealism, and Pragmatism in Charles W. Chesnutt's "The Wife of His Youth". Pap. Lang. Lit. 2018, 54, 315-342. 
94. Wang, L.C.; Calvano, L. Is Business Ethics Education Effective? An Analysis of Gender, Personal Ethical Perspectives, and Moral Judgment. J. Bus. 2015, 126, 591-602. [CrossRef]

95. Forsyth, D.R. A Taxonomy of Ethical Ideologies. J. Personal. Soc. Psychol. 1980, 39, 175-184. [CrossRef]

96. Hair, J.F.; Black, W.C.; Babin, B.J.; Anderson, R.E. Multivariate Data Analysis, 7th ed.; Prentice-Hall: Saddle River, NJ, USA, 2010.

97. Han, L.; Wang, S.; Zhao, D.; Li, J. The intention to adopt electric vehicles: Driven by functional and non-functional values. Transp. Res. Part A Policy Pract. 2017, 103, 185-197. [CrossRef]

98. Yadav, R.; Pathak, G.S. Young consumers' intention towards buying green products in a developing nation: Extending the theory of planned behavior. J. Clean. Prod. 2016, 135, 732-739. [CrossRef]

99. Graaf, S.; Van Loo, E.J.; Bijttebier, J.; Vanhonacker, F.; Lauwers, L.; Tuyttens, F.A.M.; Verbeke, W. Determinants of consumer intention to purchase animal-friendly milk. J. Dairy Sci. 2016, 99, 8304-8313. [CrossRef] [PubMed]

100. Shiu, E.; Pervan, S.J.; Bove, L.L.; Beatty, S.E. Reflections on discriminant validity: Reexamining the Bove et al. (2009) findings. J. Bus. Res. 2011, 64, 497-500. [CrossRef]

101. Leonidou, L.C.; Leonidou, C.N.; Kvasova, O. Cultural drivers and trust outcomes of consumer perceptions of organizational unethical marketing behavior. Eur. J. Mark. 2013, 47, 525-556. [CrossRef]

102. Podsakoff, P.M.; MacKenzie, S.B.; Lee, J.Y.; Podsakoff, N.P. Common method biases in behavioral research: A critical review of the literature and recommended remedies. J. Appl. Psychol. 2002, 88, 879-903. [CrossRef]

103. Norman, D. The Psychology of Everyday Things; Basic Books: New York, NY, USA, 1988.

104. Bagozzi, R.P.; Todd, F. Heatherton: A General Approach to Representing Multifaceted Personality Constructs: Application to State Self-Esteem. Struct. Equ. Modeling 1994, 1, 35-67. [CrossRef]

105. Hair, J.F.; Ringle, C.M.; Sarstedt, M. PLS-SEM: Indeed a silver bullet. J. Mark. Theory Pract. 2011, 19, 139-152. [CrossRef]

106. Cheung, G.W.; Rensvold, R.B. Evaluating goodness-of-fit indexes for testing measurement invariance. Struct. Equ. Model. 2002, 9 , 233-255. [CrossRef]

107. Tunçay Son, G.Y.; Bulut, M. A bioethical approach: Vegan and vegetarian experiences. Prog. Nutr. 2019, 21, 375-381.

108. Tobler, C.; Visschers, V.H.M.; Siegrist, M. Eating green. Consumers' willingness to adopt ecological food consumption behaviors. Appetite 2011, 57, 674-682. [CrossRef]

109. Ruby, M.B. Vegetarianism. A blossoming field of study. Appetite 2012, 58, 141-150. [CrossRef] [PubMed]

110. Anderson, E.W. Customer Satisfaction and Word of Mouth. J. Serv. Res. 1998, 1, 5-17. [CrossRef]

111. Arrieta, E.M.; González, A.D. Impact of current, National Dietary Guidelines and alternative diets on greenhouse gas emissions in Argentina. Food Policy 2018, 79, 58-66. [CrossRef]

112. Jalil, A.J.; Tasoff, J.; Bustamante, A.V. Eating to save the planet: Evidence from a randomized controlledtrial using individual-level food purchase data. Food Policy 2020, 95, 101950. [CrossRef] 